\title{
Signifikansi Modifikasi Akad dalam Transaksi Muamalah
}

Muhammad Kamal Zubair

Sekolah Tinggi Agama Islam Negeri Parepare

kamal_zubair@yahoo.co.id

\begin{abstract}
:
The existence of the contract has a crucial role in muamalah field, because there are many implications that appeared. One of them that can be an example that in Islam there is a freedom to conduct the contract by determining the condition or requirements and the form wanted voluntary and not include to the law prohibition. So, the main of contract in Islam is realised the mutual advantages among the contractors.
\end{abstract}

Keywords: Muamalah, contract, contractors

\section{Pendahuluan}

Perjanjian adalah sarana hukum terpenting yang pernah dikembangkan untuk menjamin keamanan ekonomi dan kestabilan masyarakat. Setiap orang terlibat dengan perikatan dan perjanjian, yang lahir darinya berbagai aspek kehidupan. Oleh karenanya perjanjian adalah salah satu sumber perikatan yang terpenting. Islam sebagai agama yang komprehensif memberikan aturan yang jelas mengenai perikatan dan perjanjian untuk dapat diimplementasikan dalam kehidupan.

Dalam hukum Islam ada beberapa istilah yang mengandung konsep perikatan. Pertama, ditemukan istilah "hukum akad". Sebenarnya apa yang dimaksud dengan hukum akad itu tidak lain adalah akibat hukum yang timbul dari suatu perjanjian. Kedua, para fukaha (para pakar fikih) di berbagai tempat membahas apa yang mereka sebut al-ḍamān, yang dapat dibandingkan dengan hukum perikatan dalam hukum Barat. Ketiga, para ahli hukum Islam klasik menggunakan juga istilah al-iltizām dan dengan istilah ini secara umum mereka mempergunakannya untuk perikatan-perikatan yang timbul dari 
kehendak sepihak dan kadang-kadang perikatan yang timbul dari perjanjian (Anwar, 2000: 36-39).

Ahli-ahli hukum Islam kontemporer, seperti al-Zarqā', menyebut sumber-sumber perikatan (mașādir al-iltizām) dalam Islam ada lima macam, yaitu: akad (al-'aqd), kehendak sepihak (al-irādah al-munfaridah), perbuatan merugikan (al-fi'l al-ḍār), perbuatan bermanfaat (al-fi'il al-nāfi') dan syara' (al-Zarqâ', II: 86).

Perikatan (al-iltizām) dan perjanjian (al-'aqd) dalam hukum Islam dikenal dengan beberapa istilah yang mengandung konsep tersebut, yakni ḥukm 'aqd, al-ḍamān dan al-iltizām (Muslim, 2006: 60). Sebenarnya apa yang dimaksud dengan hukum akad itu tidak lain adalah akibat hukum yang timbul dari suatu perjanjian. Ahli-ahli hukum Islam membedakan hukum akad menjadi dua; yaitu 1) hukum asli akad, yakni akibat-akibat logis dari adanya akad yang merupakan tujuan pokok disyariatkan akad. 2) hukum tambahan akad, yaitu kewajiban dan hak yang timbul dari adanya akad itu. Menurut Anwar, hukum akad tambahan menggambarkan konsep perikatan dalam hukum Islam, karena di dalamnya terkandung adanya kewajiban dan hak bagi masing-masing pihak. Sedangkan menurut al-Zarqā', hukum akad tambahan di kalangan fukaha klasik itu merupakan perikatan dalam hukum Barat.

Untuk menunjukkan perikatan, para fukaha juga menggunakan istilah al-ḍamān (tanggung jawab), yang sesungguhnya dapat dibandingkan dengan perikatan yang timbul dari perbuatan melawan hukum dalam hukum Barat. Selanjutnya, istilah iltizām juga digunakan untuk perikatan-perikatan yang timbul dari kehendak sepihak dan kadang-kadang juga untuk perikatan yang timbul dari perjanjian (al-Sanhuri, 1958: 9-10). Namun, perlu diperhatikan bahwa ulama hukum Islam tidak membuat suatu teori umum tentang perikatan dan menghimpunnya dalam satu tempat kemudian diberi nama perikatan. Hal ini disebabkan karena hukum Islam menggunakan pandangan sintesis mengenai tindakan hukum. Tindakan hukum dilihat secara keseluruhan dengan berbagai syaratnya, dan karenanya kajian hukum Islam dimulai dari tindakan hukum sebagai sumber yang melahirkan akibat hukum. Karena itu, kajian para fukaha di zaman lampau dimulai dan terpusat pada akad. Jadi, mereka tidak memulai dari akibat hukum, yaitu perikatan-perikatan yang lahir dari akad (perjanjian). 
Mengenai proses terjadinya suatu perikatan, Abdoerraoef mengemukakan tiga tahapan, yaitu: 1) Perjanjian, yaitu pernyataan dari seseorang untuk melakukan sesuatu atau tidak melakukan sesuatu dan tidak ada sangkut pautnya dengan kemauan orang lain. 2) Persetujuan, yaitu pernyataan setuju dari pihak kedua untuk melakukan sesuatu atau tidak melakukan sesuatu sebagai reaksi terhadap janji yang dinyatakan oleh pihak pertama. 3) Apabila dua buah janji dilaksanakan maksudnya oleh para pihak, maka terjadilah apa yang dinamakan akad. Maka yang mengikat masing-masing pihak sesudah pelaksanaan perjanjian bukan lagi perjanjian atau al-'ahdu, tetapi al-'aqdu (Abdoerraoef, 1970: 122-123).

Proses perikatan ini tidak terlalu berbeda dengan proses perikatan yang dikemukakan oleh Subekti yang didasarkan pada KUH Perdata. Menurutnya, perikatan adalah suatu perhubungan hukum antara dua orang atau dua pihak, berdasarkan mana pihak yang satu berhak menuntut sesuatu hal dari pihak yang lain, dan pihak yang lain berkewajiban untuk memenuhi tuntutan itu. Sedangkan pengertian perjanjian adalah suatu peristiwa di mana seseorang berjanji kepada seorang lain atau di mana dua orang itu saling berjanji untuk melaksanakan sesuatu hal (Subekti, 1992: 1). Peristiwa perjanjian ini menimbulkan hubungan di antara orang-orang tersebut yang disebut dengan perikatan. Dengan demikian, hubungan antara perikatan dengan perjanjian adalah perjanjian menerbitkan perikatan atau dengan kata lain bahwa perjanjian merupakan salah satu sumber perikatan.

Perbedaan yang terjadi dalam proses perikatan antara hukum Islam dan KUH Perdata adalah pada tahap perjanjiannya. Pada hukum perikatan Islam, janji pihak pertama terpisah dari janji pihak kedua (merupakan dua tahap), baru kemudian lahir perikatan. Sedangkan pada KUH Perdata, perjanjian antara pihak pertama dan pihak kedua adalah satu tahap yang kemudian menimbulkan perikatan di antara mereka (Dewi, 2006: 47).

Al-'Aqd berasal dari kata 'aqada - ya'qidu - 'aqdan, yang memiliki bentuk jamak al-'uqūd. Secara bahasa al-'aqd bermakna al-rabt (ikatan), al-shadd (pengencangan), al-taqwiyah (penguatan). Jika dikatakan, 'aqada al-ḥabla (mengikat tali), maksudnya adalah mengikat tali satu dengan yang lain, mengencangkan dan menguatkan ikatannya. Al-'aqdu juga bisa bermakna al-'ahdu (janji) atau al-mìthāq (perjanjian). Adapun al-'uqdah yang 
memiliki bentuk jamak al-'uqad, adalah objek ikatan atau sebutan untuk sesuatu yang diikat. Pada awalnya kata 'aqada digunakan untuk benda padat seperti tali dan bangunan. Namun kemudian dengan majaz isti'ārah kata ini juga diterapkan untuk selainnya seperti: 'aqd al-bay' (akad jual-beli), 'aqd al-'ahd (akad perjanjian), 'aqd al-nikāh (akad nikah). Dalam konteks ini, 'aqada dimaknai sebagai ilzām (pengharusan) dan iltizām (komitmen) atau irtibàt (pertautan) (al-Minawi, I: 520).

Al-'aqd, meski asalnya secara bahasa bermakna al-shadd (pengencangan), ia kemudian mengalami transformasi makna. Yang dimaksud tidak lain adalah kewajiban memenuhi apa yang disebutkan dan ditawarkan. Ini diimplementasikan pada sesuatu yang ditunggu pemenuhannya ke depan (al-Jaṣās, III: 284). Makna tersebut kemudian dalam penggunaannya lebih menonjol dan menjadi 'urf (tradisi). Karena itu, secara tradisi, al-'aqd adalah komitmen dua pihak untuk suatu perkara berikut kompensasinya (Ibn 'Ashur, IV: 115). Menurut Ibn Manzūur, "Jika Anda berkata ’āqadtuhu, maka takwilnya adalah anda mengikat (mengharuskan) dia atas hal itu dengan istịthāq (komitmen) dan membuat kontrak (kesepakatan) dan perjanjian (Ibn Manzūur, III: 297).

Dengan demikian, al-'aqd adalah transaksi dan kesepakatan, atau komitmen dengan konotasi al-istithāq. Itu tentu tidak akan terjadi, kecuali di antara dua pihak yang saling berakad. Adapun al-'ahd (janji) bisa berlangsung dari satu pihak saja. Karenanya, al-'ahd lebih umum daripada al-'aqd, karena tidak semua al-'ahd merupakan al-'aqd (akad). Sebaliknya, semua al-'aqd merupakan al-'ahd. Syariah menjelaskan al-'aqd dalam kedua maknanya sebagai al-'aqd dan al-'ahd. Di dalam penjelasan syariah tentang akad, terlihat bahwa keterikatan, komitmen dan janji itu diwujudkan dengan ijab dan kabul di antara kedua pihak yang berakad.

Al-Zarkashi, setelah menjelaskan makna al-'aqd secara bahasa, berkata, "Lalu al-'aqd ditransformasikan secara shar'i menjadi keterikatan atau pertautan ijab dengan kabul, seperti akad jual beli, nikah dan sebagainya."(al-Zarkashi, II: 397). Al-Zuhaili memberi definisi akad dengan makna pertemuan ijab dan kabul yang dibenarkan oleh shara' yang menimbulkan akibat hukum terhadap objeknya (al-Zuhaili, 1989, IV: 81). Hal senada dikemukakan oleh Anwar, bahwa akad adalah pertemuan ijab 
dan kabul sebagai pernyataan kehendak dua pihak atau lebih untuk melahirkan suatu akibat hukum pada objeknya.

Dalam buku Qawā'id al-Fiqh dinyatakan, "al-'Aqd menurut fukaha adalah keterikatan bagian-bagian tașarruf secara shar'i dengan ijab dan kabul; atau al-'aqd merupakan keterikatan atau komitmen dua pihak yang berakad dan kesengajaan keduanya atas suatu perkara. Dengan demikian, al-'aqd merupakan ungkapan mengenai keterikatan ijab dan kabul (al-Burkati, I: 383). Ijab (offer) dan kabul (acceptance) merupakan unsur terpenting dari suatu akad karena dengan adanya ijab dan kabul maka terbentuklah suatu akad (contract) (Kharofa, 2000: 10).

Hanya saja, agar dapat dinilai sebagai akad secara shar' $i$, akad harus berlangsung dalam dan untuk konteks yang sesuai dengan syariah. Akad juga membawa konsekuensi atau implikasi hukum sesuai dengan konteksnya. Oleh karena itu, dapat disimpulkan bahwa pengertian akad secara shar' $i$ adalah keterkaitan antara ijab dan kabul dalam bentuk yang disyari'atkan, yang melahirkan implikasi akad sesuai dengan konteksnya. Definisi ini menegaskan, bahwa adanya ijab dan kabul saja belum cukup, karena ijab dan kabul harus dilakukan sesuai dengan ketentuan dan bentuk yang disyariatkan. Jika semuanya ini terpenuhi, maka akad tersebut membawa implikasi.

Definisi ini bersifat lebih khusus karena terdapat pengertian akad secara istilah yang lebih luas dari pengertian ini. Namun ketika berbicara mengenai akad, pada umumnya pengertian inilah yang paling luas dipakai oleh para fukaha. Adapun pengertian akad yang bersifat lebih umum mencakup segala yang diinginkan orang untuk dilakukan, baik itu yang muncul karena kehendak sendiri (irādah munfaridah), seperti wakaf, perceraian dan sumpah, maupun yang memerlukan dua kehendak (irādatain) untuk mewujudkannya, seperti buyū' (jual-beli), ijārah (sewa-menyewa), wakālah (perwakilan) dan rahn (gadai).

Dari pengertian akad yang lebih umum ini, muncul sedikit perbedaan antara akad yang dipahami oleh fukaha dan para ahli hukum perdata. Perbedaannya adalah bahwa akad dalam pengertian yang lebih luas mencakup kehendak tunggal dan dapat melazimkan suatu transaksi. Sedangkan menurut undang-undang hukum perdata, akad mesti melibat- 
kan dua kehendak. Karena itu, wilayah akad dalam pengertian umum jauh lebih luas dibandingkan dengan akad dalam pengertian khusus.

\section{Rukun dan Syarat Terbentuknya Akad}

Telah disebutkan sebelumnya bahwa definisi akad adalah pertalian antara ijab dan kabul yang dibenarkan oleh shara' yang menimbulkan akibat hukum terhadap objeknya. Dari definisi tersebut dapat diperoleh tiga unsur yang terkandung dalam akad (Masyadi, 2002: 76-77), yaitu:

1. Pertalian ijab kabul

Ijab adalah pernyataan kehendak oleh satu pihak (mujīb) untuk melakukan sesuatu atau tidak melakukan sesuatu. Kabul adalah pernyataan menerima atau menyetujui kehendak mujīb tersebut oleh pihak lainnya (qābil). Ijab dan kabul ini harus ada dalam pelaksanaan suatu perikatan.

2. Dibenarkan oleh shara'

Akad yang dilakukan tidak boleh bertentangan dengan syariah atau halhal yang diatur dalam Alquran dan Hadis. Pelaksanaan akad, tujuan akad, maupun objek akad tidak boleh bertentangan dengan syariah. Jika bertentangan akan mengakibatkan akad menjadi tidak sah.

3. Mempunyai akibat hukum terhadap objeknya

Akad merupakan salah satu dari tindakan hukum. Adanya akad menimbulkan akibat hukum terhadap objek hukum yang diperjanjikan oleh para pihak dan juga memberikan konsekuensi hak dan kewajiban yang mengikat para pihak. Akad sebagai salah satu bentuk tindakan hukum disebut dengan tașarruf. Al-Zarqā mendefiniskan tașarruf sebagai segala sesuatu yang bersumber dari kehendak seseorang, baik berupa perbuatan maupun perkataan dan shara' menetapkan atasnya sejumlah akibat hukum (hak dan kewajiban). Dari definisi tersebut, tindakan hukum dapat dibedakan menjadi:

a. Tașarruf fi'li (perbuatan), yaitu tindakan hukum yang berupa perbuatan yang dilakukan manusia dari tenaga dan badannya, seperti mengelola tanah yang dibiarkan kosong oleh pemiliknya. 
b. Tașarruf qauli (perkataan), yaitu tindakan hukum berupa perkataan yang keluar dari lidah manusia. Tindakan hukum ini terbagi menjadi dua, yaitu:

1) Tașarruf qauli 'aqdi, adalah sesuatu yang dibentuk dari dua ucapan dua pihak yang saling bertalian, dengan mengucapkan ijab dan kabul.

2) Tașarruf qauli ghairu 'aqdi, merupakan perkataan yang tidak bersifat akad atau tidak ada ijab dan kabul. Perkataan ini ada yang berupa pernyataan dan ada yang berupa perwujudan. Perkataan yang berupa pernyataan adalah pengadaan suatu hak atau mencabut suatu hak, misalnya ikrar wakaf. Sedangkan perkataan yang berupa perwujudan adalah dengan melakukan penuntutan hak atau dengan perkataan yang menyebabkan adanya akibat hukum, misalnya gugatan.

Dari uraian di atas, jelas bahwa tindakan hukum lebih luas daripada akad dan perikatan karena tindakan hukum mencakup perbuatan dan perkataan dan juga mencakup pengikatan atau tidak. Oleh karena akad merupakan tindakan yang berupa perkataan tertentu, maka akad termasuk bagian dari tindakan hukum, karena lebih khusus daripada tindakan hukum. Sedangkan yang lebih khusus tunduk kepada yang lebih umum, tidak sebaliknya. Maka setiap akad adalah tindakan hukum dan tidaklah sebaliknya.

Di samping berbeda dengan perikatan dan tindakan hukum, akad juga berbeda dengan janji. Janji adalah informasi tentang pembentukan perikatan pada waktu yang akan datang. Dari pengertian ini dapat disimpulkan bahwa akad berbeda dengan janji, karena akad membentuk perikatan pada waktu sekarang, sedangkan janji membentuknya pada waktu yang akan datang. Di samping itu, dari segi hukum, akad berbeda dengan janji, karena akad wajib dipenuhi sedangkan janji sebaiknya dipenuhi dari segi etika.

\section{Hubungan Akad dalam Transaksi Ekonomi}

Akad secara garis besar berbeda antara satu dengan yang lainnya, dari sisi asas, tujuan, ketentuan, sifat dan hukum-hukum yang ada dalam 
akad-akad itu sendiri. Dalam kitab-kitab fikih terdapat banyak bentuk akad yang kemudian dapat dikelompokkan dalam berbagai variasi jenis-jenis akad. Masing-masing golongan akad kadang-kadang dikumpulkan dalam satu kelompok, walaupun ada perbedaan-perbedaan antara satu dengan yang lain. Mengenai pengelompokan jenis-jenis akad ini terdapat banyak variasi penggolongannya. Para fukaha mengemukakan bahwa akad dapat diklasifikasikan dalam berbagai segi, di antaranya adalah apakah akad itu diperbolehkan oleh shara' atau tidak; apakah akad itu bernama atau tidak; apakah akad itu mengikat atau tidak; dengan melihat kepada bentuk dan cara melakukan akad; tujuan diselenggarakannya akad dan lain-lain (Haroen, 2000: 108238).

Para fukaha tidak sepakat tentang jumlah akad bernama. Menurut al-Kasāni ada beberapa akad muamalah bernama sebagaimana tersusun berikut ini: (1) sewa menyewa (al-ijārah), (2) pemesanan barang (al-istișnā'), (3) jual-beli (al-bai'), (4) penanggungan (al-kafālah) (5) pemindahan utang (al-ḥawālah) (6) pemberian kuasa (al-wakālah), (7) mendamaikan (al-Ṣulh), (8) persekutuan (al-shirkah) (9) bagi hasil (al-muḍārabah), (10) hibah (alhibah), (11) gadai (al-rahn), (12) penggarapan tanah (al-muzāra'ah) (13) pemeliharaan tanaman (al-musāqah) (14) penitipan (al-wadi'ah) (15) pinjam pakai (al-'āriyah), (16) pembagian (al-qismah) (17) wasiat-wasiat (al-wașāyāa) (18) perutangan/al-qard (al-Sanhuri: 87). Sedangkan ahli hukum lainnya menyebut beberapa jenis akad lain lagi, menurut perhitungan al-Zarqā', macam-macam bentuk akad secara keseluruhan mencapai 25 akad khusus (al-Zarqā', I: 538).

Akad muamalah dalam bidang ekonomi menurut sifat partisipasi dari para pihak yang terlibat dalam transaksi, secara prinsip dapat dikategorikan menjadi tiga:

1. Akad pertukaran tetap, yang lazimnya adalah kegiatan perdagangan. Sesuai dengan sifatnya, akad ini umumnya memberikan kepastian hasil bagi para pihak yang melakukan transaksi.

2. Akad penggabungan atau pencampuran, yang lazimnya adalah kegiatan investasi. Akad ini umumnya hanya memberikan kepastian dalam hubungan antar pihak dan jangka waktu dari hubungan tersebut, namun umumnya tidak dapat memberikan kepastian hasil. 
3. Kegiatan penguasaan sementara, yang lazimnya adalah kegiatan sewamenyewa. Akad ini umumnya memberikan kepastian dalam manfaat yang diterima oleh para pihak sehingga dapat terjadi pertukaran maupun penggabungan atau pencampuran antara ayn dengan ayn, ayn dengan dayn dan dayn dengan dayn.

Dalam menerapkan akad-akad ini pada transaksi ekonomi terdapat empat prinsip dalam perikatan secara syariah yang perlu diperhatikan (Hayes, 2007: 85), yaitu:

1. Tidak semua akad bersifat mengikat kedua belah pihak ('aqad lazim), karena ada kontrak yang hanya mengikat satu pihak ('aqad jaiz).

2. Dalam melaksanakan akad harus dipertimbangkan tanggung jawab yang berkaitan dengan kepercayaan yang diberikan kepada pihak yang dianggap memenuhi syarat untuk memegang kepercayaan secara penuh.

3. Larangan mempertukarkan kewajiban (dayn) melalui transaksi penjualan sehingga menimbulkan kewajiban (dayn) baru atau yang disebut bay' al-dayn bi al-dayn.

4. Akad yang berbeda menurut tingkat kewajiban yang masih bersifat janji (wa'd) dengan tingkat kewajiban yang berupa sumpah ('ahd).

\section{Signifikansi Modifikasi Akad dalam Aktivitas Muamalah}

Sebagaimana dikemukakan sebelumnya bahwa definisi akad adalah pertalian antara ijab dan kabul yang dibenarkan oleh syara' yang menimbulkan akibat hukum terhadap objeknya. Ketentuan yang dilakukan oleh para pihak tersebut mempunyai implikasi terhadap pemenuhan akan hak dan kewajiban masing-masing yang mengakibatkan terikat oleh tindakan hukum yang telah disepakati. Oleh karena itu, dalam Islam dikenal kaedah akad yang menyatakan: "Pada asasnya, akad (perjanjian) adalah kesepakatan kedua belah pihak dan akibat hukumnya adalah apa yang mereka tetapkan melalui janji" (Rahman, 1975: 44).

Uraian di atas merupakan dasar perjanjian dalam Islam untuk dipandang sebagai sesuatu yang sah (legal), dapat diterima dan dibolehkan untuk dilaksanakan. Dengan tidak meninggalkan dasar-dasar tersebut, 
perjanjian dalam Islam juga harus dilihat dari sisi kebebasan dalam melakukan perjanjian, karena asas ini merupakan asas umum yang terdapat dalam akad (perjanjian).

Pandangan Islam tentang akad sebenarnya tidak ada batasan yang ketat tentang bagaimana perjanjian tersebut dibentuk. Beberapa pembatasan yang ada dalam kitab fikih klasik sebenarnya sebagian besar adalah cakupan dari beberapa bentuk perjanjian yang ada pada masa kitab tersebut disusun. Walaupun banyak kitab-kitab fikih yang membatasi pembahasan akadnya dengan membahas bentuk-bentuk tertentu dari akad, namun pembahasan tersebut sebenarnya pembahasan secara sekilas tentang hukum perjanjian dalam Islam yang ditetapkan oleh para fukaha. Penyebutan bentuk-bentuk akad oleh para fukaha adalah berdasarkan akad yang umum berlaku pada masanya. Jika peradaban semakin maju, maka tidak menutup kemungkinan untuk mengembangkan bentuk-bentuk akad. Jadi pengembangan macam dan bentuk akad selanjutnya tidak ada larangan (Niazi: 77).

Keberadaan akad dapat ditelaah dengan melihat beberapa kaedah atau prinsip utama hukum muamalah dalam Islam, di antaranya: Pertama, pada dasarnya segala bentuk muamalah adalah boleh kecuali yang ditentukan selain dari Alquran dan Sunnah. Kedua, muamalah dilakukan atas dasar sukarela tanpa mengandung unsur-unsur paksaan. Ketiga, muamalah dilakukan atas dasar pertimbangan mendatangkan manfaat dan menghindari mudharat dalam kehidupan masyarakat. Keempat, muamalah dilaksanakan dengan memelihara nilai keadilan, menghindari unsur-unsur penganiayaan, unsur mengambil kesempatan dalam kesempitan (Baasyir, 1993: 10).

Salah satu faktor penting dalam terciptanya akad adalah adanya unsur kerelaan antara kedua belah pihak yang meleburkan diri ke dalam ikatan perjanjian. Akad tersebut dapat terwujud dengan adanya ucapan dari salah satu pihak kemudian pihak yang lain mengerjakan sesuatu yang menunjukkan kehendaknya, baik berupa tulisan, isyarat, maupun penyerahan. Di samping itu suatu akad juga dapat terjadi dengan adanya ikatan antara dua perilaku yang dapat menggantikan posisi ucapan tersebut, baik berupa tindakan maupun isyarat.

Menurut ulama mazhab Hambali dan Maliki, pihak-pihak yang berakad, bebas menggunakan persyaratan dalam suatu akad selama syarat- 
syarat itu bermanfaat bagi kedua belah pihak. Misalnya menentukan sifatsifat tertentu yang bermanfaat terhadap barang yang dibeli. Namun demikian, mereka tetap menyatakan bahwa syarat tersebut tidak boleh bertentangan dengan kehendak syara' (Dahlan, 1996, I: 67).

Berdasarkan penjelasan di atas dapat dipahami bahwa sebenarnya inti dari terciptanya suatu akad secara umum adalah terwujudnya dua kehendak orang yang berakad dan ada kesesuaian antara keduanya untuk memunculkan kelaziman (kewajiban) yang bersifat shar'i pada kedua pihak, yang diindikasikan dari adanya suatu ungkapan, tulisan atau tindakan.

Dengan demikian dapat dipahami bahwa esensi akad adalah pencapaian kesepakatan kedua belah pihak, di mana suatu perbuatan seseorang dianggap sebagai suatu pernyataan kehendak. Dalam akad, pernyataan kehendak dapat dilakukan berupa tindakan yang menurut kebiasaan dianggap sebagai akad. Tindakan tersebut juga dianggap sebagai pernyataan kerelaan at as suatu persyaratan dari suatu pihak. Suatu kebiasaan selama tidak melanggar syara' adalah dibolehkan dan dapat diambil sebagai dasar hukum. Sesungguhnya hukum asal dalam bermuamalah adalah boleh dan tidak diberikan penjelasan dalam melaksanakannya, karenanya maka pelaksanaannya wajib dikembalikan kepada kebiasaan yang telah berlaku.

Modifikasi dalam bidang muamalah sangat dimungkinkan karena pada dasarnya tidaklah ada syariat yang bersifat absolut, mutlak dan berlaku untuk segala waktu, tempat dan keadaan. Dalam hukum Islam terdapat maqāṣid al-sharì'ah yang berisi maksud atau tujuan dari disyariatkan hal tersebut. Guna mencapai tujuan itu, syariat Islam ada yang bersifat dinamis, dapat berubah sesuai kebutuhan sosial atau kontekstual. Modifikasi sebenarnya tidak akan melanggar prinsip-prinsip hukum Islam dalam bidang muamalah. Hal ini dikarenakan dalam fikih muamalah, ijtihad bersifat "terbuka luas", artinya segala sesuatu boleh diadakan modifikasi selama tidak bertentangan atau melanggar larangan yang sudah ditentukan dalam Alquran dan Sunnah Nabi. Inilah yang memungkinkan hukum perikatan Islam dapat mengikuti perkembangan zaman. 


\section{Penutup}

Keberadaan akad memiliki peranan yang krusial dalam lapangan muamalah dengan banyaknya implikasi yang ditimbulkan. Salah satunya adalah bahwa dalam Islam terdapat kebebasan untuk melakukan akad dengan menentukan segenap syarat dan bentuk akad yang diinginkan oleh para pihak, asalkan akad tersebut dilakukan secara sukarela serta tidak termasuk dalam larangan syara'. Inti akad yang dilakukan dalam Islam adalah terciptanya kemaslahatan bagi para pihak yang melakukannya.

\section{Daftar Pustaka}

Abdoerraoef, Al-Qur'an dan Ilmu Hukum: a Comparative Study. 1970. Jakarta: Bulan Bintang.

Al-Burkati, Muhammad 'Amim al-Ihsan al-Mujadidi. 1407. Qawā'id al-Fiqh. Kratisa: al-Șadf Bublisyirz, cet. 1, I.

Al-Jașās. 1405. Aḥkām al-Qur'ān li al-Jașās, ed. M. Șadiq al-Qamhawi. Beirut: Dār Ihya at-Turath al-'Arabi, III.

Al-Minawi. 1410. Al-Ta'ārif, ed. M. Ridhwan ad-Dayah. Beirut: Dār Fikr alMu'āsir, I.

Al-Sanhuri, Abdur Razzaq. 1958. Mașādir al-Ḥaq fī al-Fiqh al-Islāmi, Dirāsah Muqāranah bi al-Fiqh al-Garbi. Tk.: Dār al-Hana Li al-Thiba'ah wa al-Nasyr, I.

. tt. Nazariyyah al-'Uqūd. Beirut: Dār al-Fikr.

Al-Zarqā', Musthafa Ahmad, Madkhal al-fiqh al-'Am (Dār al-Fikr, Beirut, tt.)

Al-Zarkashi, Muhammad bin Bahadur bin Abdillah, al-Manthūr fì al-Qawā'id li Zarkashi, ed. Dr. Taysir Faiq Ahmad Mahmud, cet. 2, (Kuwait: Wuzarah al-Awqaf wa Shu'un al-Islamiyah, 1405), II.

Anwar, Syamsul. 2007. Hukum Perjanjian Syariah, Studi tentang Teori Akad dalam Fiqh Muamalat. Jakarta: Raja Grafindo Persada.

. 1999/2000. "Teori Kausa dalam Hukum Perjanjian Islam (Suatu Kajian Asas Hukum)", dalam Laporan Penelitian, IAIN Sunan Kalijaga Yogyakarta.

Baasyir, Ahmad Azhar. 1993. Asas-asas Hukum Muamalah: Hukum Perdata Islam. Yogyakarta: UII Press. 
Dahlan, Abdul Azis, dkk. 1996. Ensiklopedia Hukum Islam. Jakarta: PT. Ichtiar baru Van hoeve, I.

Dewi, Gemala. 2006. Hukum Perikatan Islam di Indonesia. Jakarta: Kencana. Haroen, Nasrun. 2000. Fiqh Muamalah. Jakarta: Gaya Media Pratama. Ibn 'Ashūr, al-Taḥrīr wa al-Tanwìr, dalam al-Maktabah al-Shāmilah, IV. Ibn Manzūur. tt. Lisān al-'Arab, Beirut: Dār al-Ṣadir, cet. 1, III.

Kharofa. 2000. Transaction in Islamic Law. Kuala Lumpur: A.S. Noordeen. Masyadi, Ghufran. 2002. Fiqh Muamalah Kontekstual. Jakarta: RajaGrafindo Persada.

Muslim, Muslihun. 2006. Fiqh Ekonomi dan Positivisasinya di Indonesia. Mataram: LKIM IAIN Mataram.

Niazi, Liaquat Ali Khan. tt. Islamic Law of Contract. Lahore: Research Dyal Sing Trust Library.

Rahman, Asmuni. 1975. Qaidah-Qaidah Fiqhi. Jakarta: Bulan Bintang.

Satrio, J. 1993. Hukum Perikatan: Perikatan yang Lahir dari Undang-Undang Bagian Pertama. Bandung: PT. Cipta Aditya Bakti.

Subekti, 1992. Hukum Perjanjian. Jakarta: Intermasa.

Vogel, Frank E. dan Hayes, Samuel L. 2007. Hukum Keuangan Islam, Konsep, Teori dan Praktek. Bandung: Nusamedia. 